\title{
HETEROSIS ANALYSIS IN PUMPKIN (CUCURBITAMOSCHATA DUCH. EX. POIR)
}

\author{
Gazi Md Mohsin*, Md Sajedur Rahman ${ }^{1}$, Farruk Ahamed ${ }^{1}$ \\ AND MD HASANUZZAMAN ${ }^{2}$ \\ Department of Agriculture, Noakhali Science and Technology University, \\ Noakhali-3814, Bangladesh
}

Key words: Pumpkin, Genetic parameters, Heterosis, Crossing, Hybrid

\begin{abstract}
The research was carried out at Lal Teer Seed Ltd. Gazipur to determine the heterosis of yield and yield contributing traits of pumpkin (Cucurbita moschata Duch. ex Poir.). Six diverse pumpkin parents (viz. CM-1, BARI Mistikumra-1, CM-20 and CM-8) and their 30 F1 hybrids derived from 6X6 diallel including reciprocal were used as research materials. Thirteen genetic parameters [viz. days to first male flower opening, days to first female flower opening, number of flowers (male and female) per plant, fruit length and diameter $(\mathrm{cm})$, fruit weight $(\mathrm{kg})$, flesh thickness $(\mathrm{cm})$, brix $(\%)$, number of fruits per plant, number of seeds per fruit, 100-seeds weight $(\mathrm{g})$, yield per plant $(\mathrm{kg})]$ were estimated. The results revealed significantly higher and positive heterosis and expected negative effects for different important characters of pumpkin. The two cross combinations namely; CM-1 $\times$ BARI Mistikumra-1 and CM- $8 \times$ CM-1 were identified as the promising hybrids which showed the significant higher heterosis, heterobeltiosis and standard heterosis. These finding suggest that cross combinations of indigenous $x$ exotic parents may be beneficial for fruit yield, particularly when used as commercial hybrids. The results showed that these two combinations gave the most promising hybrids (F1), so these two F1 lines were registered in National Seed Board (NSB) of Bangladesh as Hajee $F_{1}$ and Danesh $F_{1}$ hybrid varieties.
\end{abstract}

\section{Introduction}

Pumpkin (Cucurbita moschata Duch. Ex. Poir) is the most important seed propagated monoecious climbing vegetable crop that belongs to the family Cucurbitaceae, with the chromosome number $2 n=40^{(1)}$. It is one of the most common fruit vegetables in Bangladesh. It is locally known as Misty kumra or Misty lau or Misty kadu. It is grown round the year in the country and has the longest storability among the cucurbits. The well-matured fruits can be stored for 2 to 4 months $^{(2)}$. Due to its good storability, nutritive

\footnotetext{
*Author for correspondence: <mohsinbreeder97@gmail.com>. 1R\&D, Lal Teer Seed Limited, Bashon, Gazipur, Bangladesh. ${ }^{2}$ Department of Genetics \& Plant Breeding. Faculty of Agriculture. Hajee Mohammad Danesh Science \& Technology University, Dinajpur, Bangladesh.
} 
value, long period of availability, better transport potential and reasonable market price, it has a great demand in Bangladesh.

Pumpkin is grown in all over the country and in most areas, local land races are cultivated. The yield of these land races is very low. During 2010-2011, average yield was $7.53 \mathrm{t} / \mathrm{ha}^{(3)}$ which is much lower than our neighboring country India ${ }^{(4)}$. During 2010-2011, the average pumpkin production was $9.3 \mathrm{t}$ /ha in India, $18.4 \mathrm{t}$ / ha in China, $18.6 \mathrm{t}$ /ha in Russia, $16.3 \mathrm{t}$ ha in Mexico, $29.4 \mathrm{t}$ /ha in Italy and $21.4 \mathrm{t}$ ha in USA ${ }^{(4)}$.The per capita consumption of vegetable in Bangladesh is about $50 \mathrm{~g} / \mathrm{day}$, which is the lowest among the countries of South and South Asia. However, the daily per capita requirement is $220 \mathrm{~g}^{(5)}$. There is a big gap between the demand and supply of vegetables in Bangladesh. Thus, improvement of crop yield and production of this vegetable crop is most desirable and important to mitigate the future demand.

Both green and ripe pumpkins are used as vegetables. This fruit vegetables supply carbohydrates, soluble fiber and beta-carotenoid from the flesh, and protein, vegetable oil and vitamin E from edible seeds. Pumpkin contains carotene which is very essential for eye sight development. Its immature fleshy green leaves, tender shoots, male and female flowers are also used as vegetables, and contain appreciable amount of vitamins and minerals. It is important as a good source of minerals, fibres, vitamins, antioxidants and phytonutrients $(6,7)$ and this makes the fruit wholesome and healthy for human consumption. Some authors have reported that pumpkin fruits have high medicinal values $^{(8)}$. Pumpkin seed is an excellent source of protein and also has pharmacological activities such as anti-diabetic ${ }^{(9)}$, antifungal ${ }^{(10)}$, antibacterial and anti-inflammation activities $^{(11)}$ and used for parasitic diseases cure in African countries ${ }^{(12)}$ and antioxidant effects $^{(13)}$.

Fruit yield is a complex trait and governed by many genes or poly genes that is determined by complex associations among several agronomic traits ${ }^{(14,15)}$. In plant breeding program, direct selection on the basis of phenotypical characters for yield as such could be misleading. Yield and yield contributing traits like fruit weight, fruit per plant, fruit length, fruit diameter and 100-seed weight, etc. must be taken into consideration for variety development ${ }^{(16)}$.

Exploitation of hybrid vigor is considered to be outstanding achievements of plant breeding. The scope of exploitation of hybrid vigor will depend upon the available pollination mechanism. The literature available in the field of plant breeding reveals that the exploitation of hybrid vigor is more feasible to cross-pollinated crops than selfpollinated ones. Being a cross-pollinated crop, pumpkin has considerable scope for commercial exploitation of heterosis and virtually obligatory out crossing system in pumpkin has opened the scope for the development of hybrid variety in this crop.

Understanding the inheritance of yield and yield related traits in advance would be important to maximize the use of genetic potential in an effective breeding program. In 
pumpkin, such genetic information about Bangladeshi genotypes is rarely available that creates a problem for the planning of a sound breeding program to improve the basic yield and associated plant traits of the crop. Very few studies have been conducted to find the genetic analysis of yield and yield related traits of pumpkin. Hence, enhancement of crop yield is still an important goal for pumpkin breeders in Bangladesh.

Therefore, considering the importance of pumpkin and in view of the abovementioned facts, the present study was undertaken (i) to estimate the heterosis of some local and exotic pumpkin genotypes and (ii) to select the best cross combinations to release as hybrid varieties

\section{Materials and Methods}

Experimental site: The experiment was conducted at the R\&D of Lal Teer Seed Ltd. Gazipur in 2014.

Plant materials: Six diverse pumpkin genotypes e.g. CM1 (Lal Teer Seed), CM5 (Meherpur), CM8 (AVRDC), CM14 (Thailand), BARI MistiKumra-1 (BARI) and CM20 (Thailand) were selected. These parents were crossed in a diallel mating system including the reciprocals and all the six parents, their $15 \mathrm{~F}_{1 \mathrm{~S}}$ and 15 reciprocal $\mathrm{F}_{1} \mathrm{~S}$ were studied.

Experimental design and Layout: The experiment was set in a randomized block design with three replications. There were three plants per replication. The spacing adopted was $(4.0 \times 1.0) \mathrm{m}^{2}$. A good drainage system was maintained for draining out of rain water from the field.

Application of manure and fertilizers: Cow dung, Urea, TSP, MP, Gypsum, Zinc sulphate and Borax were applied @ 2kg, 66 g, 92 g, 88 g, 65 g, $1.65 \mathrm{~g}$ and 3 g per pit respectively. The entire amount of cow dung, TSP, Zinc sulphate, Gypsum, Borax and one-third of the urea and MP were applied at the time of final land preparation while the rest of the urea and MP were applied at two equal installments, 15 and 30 days after transplanting ${ }^{(17)}$.

At the time of transplanting, Dursbarn 20 EC and Ridomil MZ 68 WP were used at the rate of $5 \mathrm{ml} \Lambda$ and $3 \mathrm{~g} \Lambda$, respectively for soil treatment. Irrigation was given as and when necessary. Weeding was done after every 15 days of transplanting.

Data collection and analysis: Data were collected on the thirteen morphological traits associated with yield from randomly selected ten plants from each genotype. The thirteen genetic parameters were days to first male flower opening, days to first female flower opening, number of flowers (male and female) per plant, fruit length and diameter $(\mathrm{cm})$, fruit weight $(\mathrm{kg})$, flesh thickness $(\mathrm{cm})$, brix $(\%)$, number of fruits per plant, number of seeds per fruit, 100- seeds weight $(\mathrm{g})$, yield per plant $(\mathrm{kg})$. 
Statistical analysis: Estimation of heterosis: Heterosis expressed as percent of increase of $F_{1}$ hybrid over mid parent (average or relative heterosis), better parent (heterobeltiosis) and commercial check (standard heterosis) were computed for each character using the following formulae ${ }^{(19)}$.

a. Relative Heterosis, $\mathrm{H}(\%)$ over mid parent $(\mathrm{MP})=\frac{\overline{\mathrm{F}_{1}}-\overline{\mathrm{MP}}}{\overline{\mathrm{MP}}} \times 100$

b. Heterobeltiosis, $\mathrm{H}(\%)$ over better parent $(\mathrm{BP})=\frac{\overline{\mathrm{F}_{1}}-\overline{\mathrm{BP}}}{\overline{\mathrm{BP}}} \times 100$

c. Standard Heterosis, $\mathrm{H}(\%)$ over check $(\mathrm{CV})=\frac{\overline{\mathrm{F}_{1}}-\overline{\mathrm{CV}}}{\overline{\mathrm{CV}}} \times 100$

Where, $\overline{\mathrm{F}}_{1}, \overline{\mathrm{MP}}, \overline{\mathrm{BP}}$ and $\overline{\mathrm{CV}}$ are the mean of $\mathrm{F}_{1}$, two parental populations (MP), better parent $(\mathrm{BP})$ and check variety $(\mathrm{CV})$, respectively.

Significant difference of $\mathrm{F}_{1}$ with $\mathrm{MP}, \mathrm{BP}$ and $\mathrm{CV}$ were tested using ' $\mathrm{t}$ ' test and was calculated by the formula given below:

I. $[\mathrm{t}]=\frac{\overline{\mathrm{F}_{1}}-\overline{\mathrm{MP}}}{\mathrm{SED}} \times 100 \quad$ Where, $\mathrm{SED}=\sqrt{2 \mathrm{EMS} / \mathrm{r}}$

II. $[\mathrm{t}]=\frac{\overline{\mathrm{F}_{1}}-\overline{\mathrm{BP}}}{\mathrm{SED}} \times 100 \quad$ Where, $\mathrm{SED}=\sqrt{2 \mathrm{EMS} / \mathrm{r}}$

III. $[\mathrm{t}]=\frac{\overline{\mathrm{F}_{1}}-\overline{\mathrm{CV}}}{\mathrm{SED}} \times 100 \quad$ Where, $\mathrm{SED}=\sqrt{2 \mathrm{EMS} / \mathrm{r}}$

Where, SED $=$ Standard error of difference, EMS $=$ Error mean square and $\mathrm{r}=$ Replication, SED (Standard error of difference $)=\sqrt{ }($ Variance $/$ Sample size $)$.

\section{Results and Discussion}

Heterosis were estimated for individual crosses of 30 hybrids in yield and yield contributing characters over mid parent, better parent (heterobeltiosis) and standard (check) variety. The findings have been presented in Tables 1, 2 and 3, respectively. The performance of heterosis over mid parent, better parent (heterobeltiosis) and standard variety were discussed character-wise in the following manner.

Days to first male flower opening: The importance of days to flowering and fruiting for developing early maturing crops is well known. Days to first male flowering varied from 36.17 in parent CM-20 to 61.17 in BARI Mistikumra-1, while F1 hybrids the range was 36.90 in $\mathrm{CM}-20 \times \mathrm{CM}-1$ to 63.43 in $\mathrm{CM}-20 \times \mathrm{CM}-14$ in the $\mathrm{F}_{1}$ hybrids. Out of 30 cross combinations 15 hybrids manifested significant negative heterosis, that is earliness over their mid parents in respect of days to first male flower opening. Only two crosses having significant negative heterobeltiotic effect and negative significant standard heterosis were found in all crosses for days to male flower opening. Heterosis over mid parent for this trait ranged from $-0.88^{*}$ in $\mathrm{CM}-14 \times \mathrm{CM}-5$ to $40.49^{* *}$ in $\mathrm{CM}-20 \times \mathrm{CM}-14$ percent. The highest heterosis over mid parent $\left(40.49^{* *}\right)$, better parent $\left(75.39^{* *}\right)$ were recorded in the cross CM-20 $\times$ CM-14 followed by the crosses CM-20 $\times$ CM-5, CM-1 $\times$ 


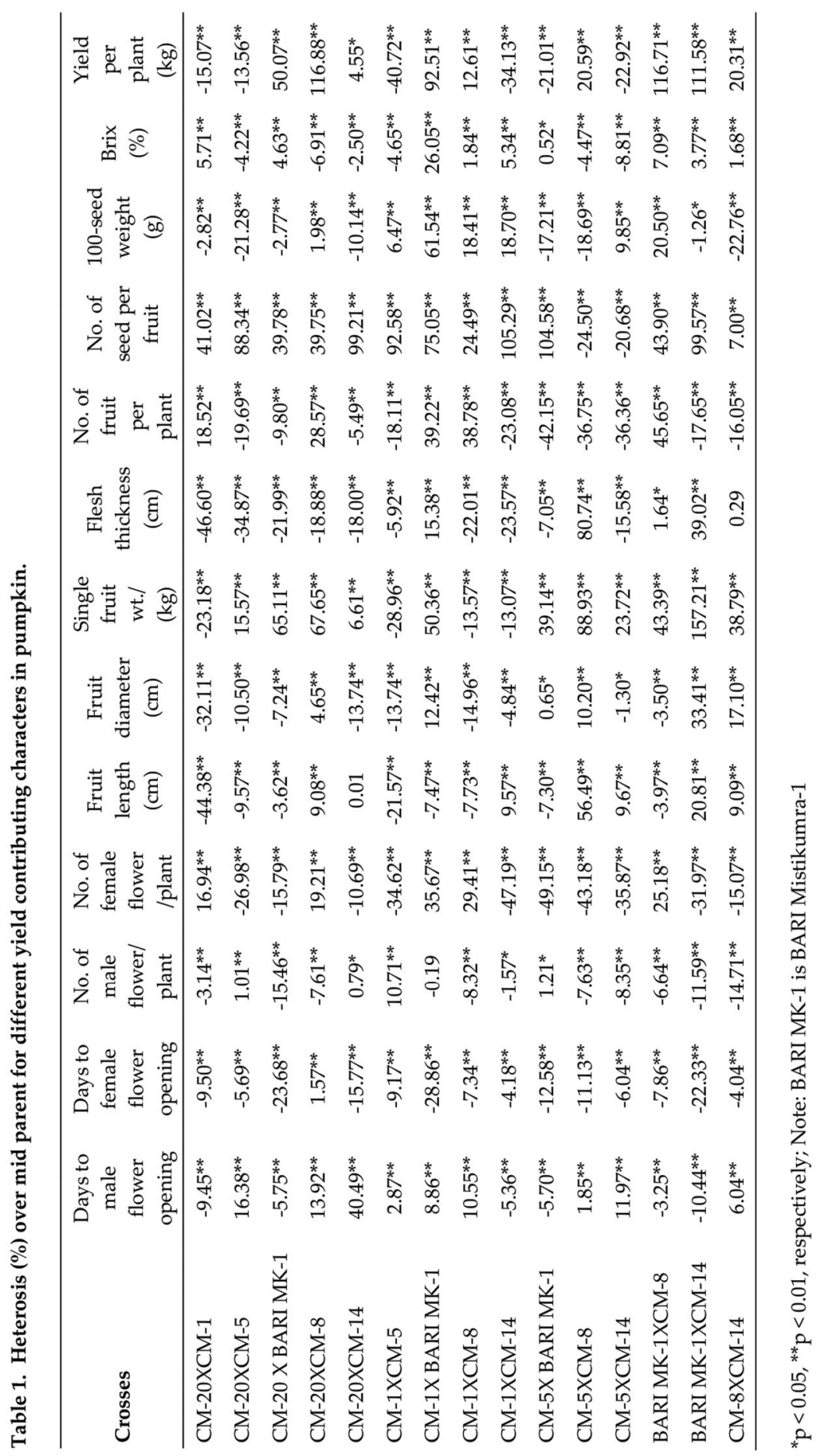




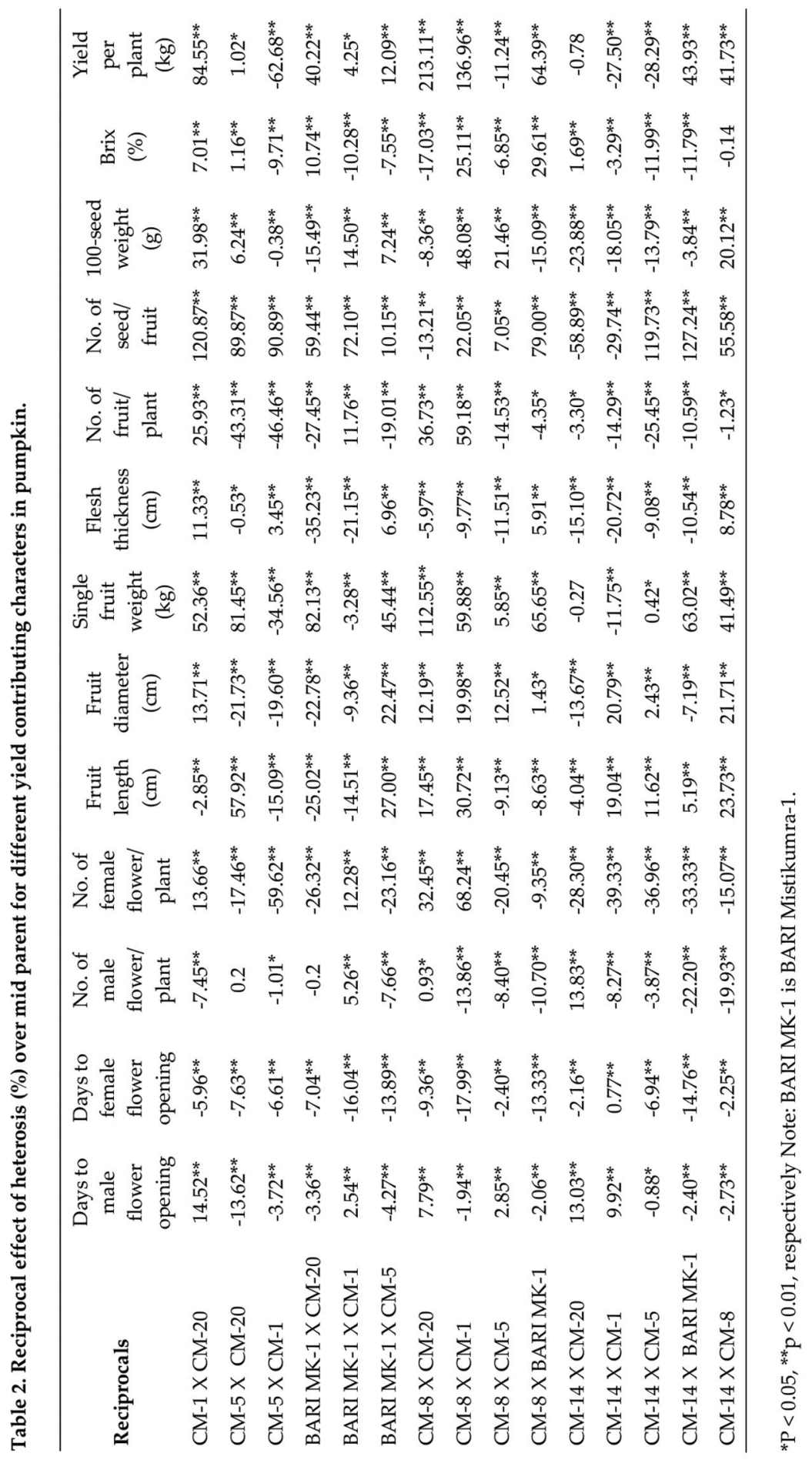




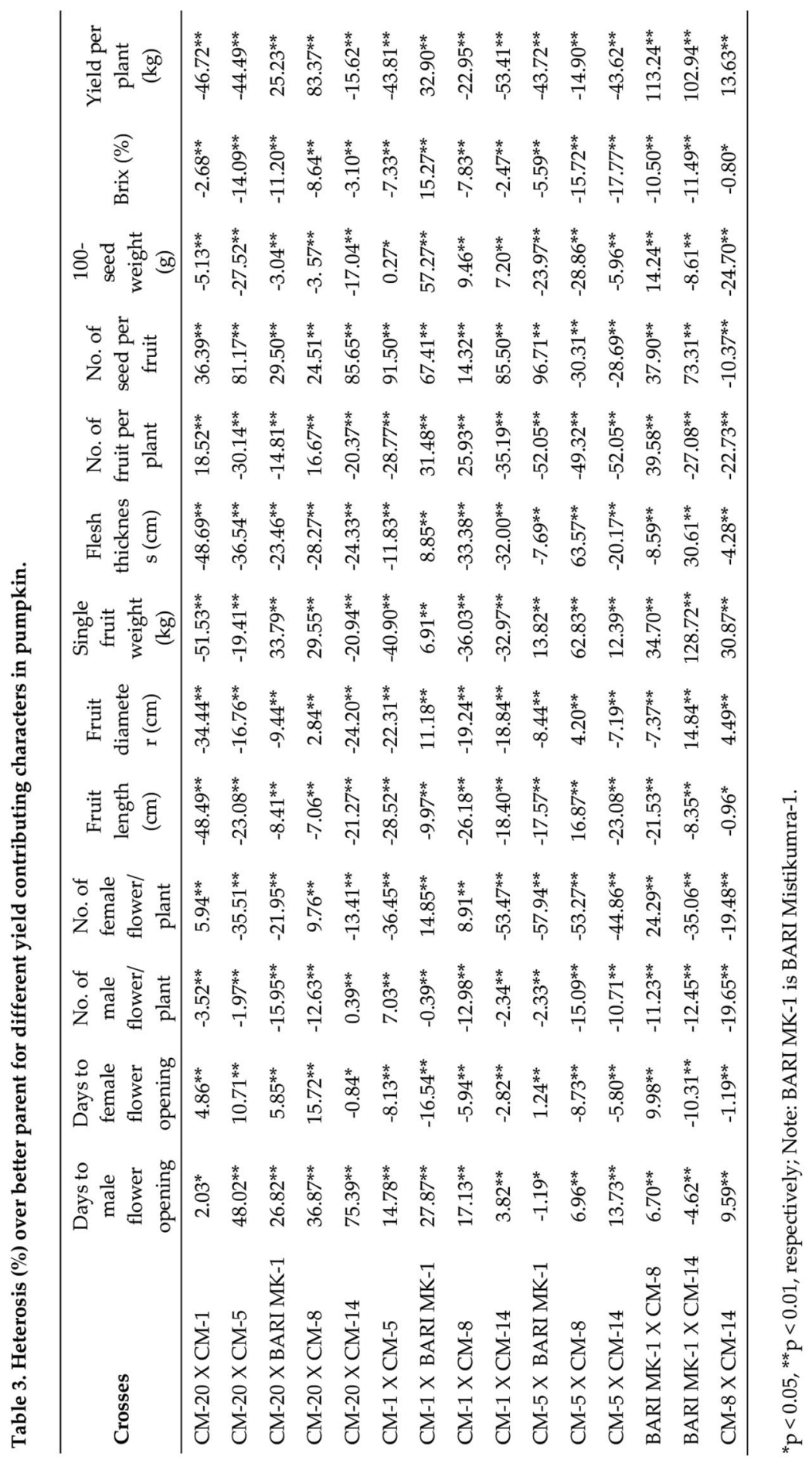


CM-20, BARI Mistikumra-1×CM-20, CM-8×CM-20,CM-1×BARI Mistikumra-1, CM$20 \times \mathrm{CM}-8$ and CM-14×CM-20.In bitter gourd it was reported that $17 \mathrm{~F}_{1}$ hybrids showed significant negative heterosis for this trait ${ }^{(20)}$. In another report 26 out of 30 crosses were earlier flowering than their better parent found in snake gourd ${ }^{(21)}$.

Days to first female flower opening: Days to first female flower opening varied from 43.90 in parent CM-20 to 77.87 in parent BARI Mistikumra-1 and 43.53 in CM-20xCM-14 to 61.73 in BARI Mistikumra-1×CM-8 hybrid combinations. Here we found that male flowering was earlier as compared to female flowering in all genotypes studied. Among the six parental lines, parent CM-20 was the earliest in both male and female flower opening which was followed by parent CM-1 and CM-8. On the other hand, CM-20XCM1 was the earliest for male flowering and $\mathrm{CM}-20 \times \mathrm{CM}-14$ for female flowering among all the hybrid combinations that was followed by CM-20×CM-1, CM-20×BARI Mistikumra-1 and CM-1×BARI Mistikumra-1.

For commercial purpose negative heterosis is desirable for this trait. Here, out of 30 cross combinations 29 hybrids showed significant negative heterosis i.e., earliness in female flower opening. The heterosis over mid parent ranged from $-28.86^{* *}$ in CM$1 \times$ BARI Mistikumra- 1 to $0.77^{* *}$ in CM-14×CM-1. The highest and desirable heterosis over mid parent was observed in the cross CM-1×BARI Mistikumra- $1\left(-28.86^{* *}\right)$ followed by CM-20×BARI Mistikumra-1(-23.68**), BARI Mistikumra-1 $\times$ CM-14 $\left(-22.33^{* *}\right)$ and CM$8 \times \mathrm{CM}-1\left(-17.99^{* *}\right)$. Heterobeltiosis varied from $-16.75^{* *}$ in $\mathrm{CM}-8 \times \mathrm{CM}-1$ to $28.93^{* *}$ in BARI Mistikumra- $1 \times \mathrm{CM}-20$ for this trait. The highest and desirable heterosis over better parent was observed in the cross CM- $8 \times \mathrm{CM}-1\left(-16.75^{* *}\right)$ followed by CM-1×BARI Mistikumra- 1 $\left(-16.54^{* *}\right)$, BARI Mistikumra-1×CM-14(-10.31**), CM-5×CM-8(-8.73**) and CM-1×CM-5 $\left(-8.13^{* *}\right)$. The negative significant standard heterosis were found in all crosses for days to female flower opening. It was ranged from $-27.71^{* *}$ in BARI Mistikumra-1×CM-8 to 49.02** in CM-20×CM-14. The hybrids CM-1×BARI Mistikumra-1, CM-8×CM-1 and CM$8 \times \mathrm{CM}-20$ showed significant negative heterosis over mid, better parental values and standard heterosis for female flower opening. Similar reports in better parent also studied in snake gourd(21), in pumpkin(22), in Bottle gourd(23), in cucumber(24), in pumpkin(25). Also found high heterosis over the better parent for female flower opening(26).

It was reported, out of 28 crosses of sweet gourd, 14 hybrids showed highly significant desired negative heterosis in case of days to first female flower opening ${ }^{(27)}$. The highest $(-16.89 \%)$ negative heterosis for days to first female flower opening was recorded in the cross CM020 $\times \mathrm{CM} 099$ followed by the crosses CM044 $\times$ CM073, CM073 $\times$ CM099, CM026 ×CM099 and CM073 ×CM118, respectively. Similar trends of results were also reported that $-36.20 \%$ heterosis over better parent found in pumpkin ${ }^{(28)}$. Negative heterosis is desirable for having early genotypes. So, these crosses may be considered as the most promising for this trait. 
Number of male flower per plant: Out of 30 cross combinations 7 crosses $\left(13.83^{* *}\right.$ in CM$14 \times \mathrm{CM}-20$ followed by $10.71^{* *}$ in $\mathrm{CM}-1 \times \mathrm{CM}-5,0.93^{*}$ in $\left.\mathrm{CM}-8 \times \mathrm{CM}-20\right)$ showed positive, 19 showed negative heterosis over mid parent significantly. Only three cross combinations showed insignificant heterosis (-0.19 in CM-1×BARI Mistikumra-1). Other hand only four crosses showed positive heterobeltiotic effects for this trait. By the way all cross combinations showed highly negative heterosis for standard variety.

Number of female flower per plant: Twenty- one cross combinations manifested significant negative while nine hybrid combinations manifested positive heterosis for this trait. Positive heterosis varied from $12.28^{* *}$ to $68.24^{* *}$ over their mid parent. Highest positive heterosis was found $68.24^{* *}$ in $\mathrm{CM}-8 \times \mathrm{CM}-1$ followed by $35.67^{* *}$ in CM-1×BARI Mistikumra-1 and $32.45^{* *}$ in CM-8XCM-20. The highest heterobeltiotic effect was found $41.58^{* *}$ in CM-8×CM-1 followed by $24.29^{* *}$ in BARI Mistikumra-1×CM-8, 21.95** in CM$8 \times \mathrm{CM}-20$ and $14.85^{* *}$ in CM-1×BARI Mistikumra-1.The positive standard significant heterotic effect showed $15.14^{* *}$ in $\mathrm{CM}-8 \times \mathrm{CM}-1$ for this trait. It was also found high heterosis over the better parent for number of female flowers, per plant in pumpkin ${ }^{(26)}$.They reported both positive and negative heterosis was observed for different qualitative and quantitative characters in $\mathrm{F}_{1}$ hybrids of sweet gourd (2). They recorded the significant $(\mathrm{p} \varangle 0.05)$ positive mid parent heterosis $(30.88 \%)$ for female flowers per plant by the hybrid OP $20 \times \mathrm{OP} 02$.

Fruit length: Out of 30 cross combination, 15 hybrids exhibited significant positive heterosis for this trait. Significant positive heterosis in the F1 hybrids ranged from $5.19 \%$ in CM-14×BARI Mistikumra-1 to $57.92 \%$ in CM-5×CM-20. The highest heterosis was found $57.92 \%$ in CM-5×CM-20 followed by $56.49 \%$ in CM-5×CM $-8,30.72 \%$ in CM-8×CM1 over the mid parent. The highest heterobeltiotic effect was found $34.33 \%$ in CM-5 $\times \mathrm{CM}-$ 20 followed by $16.87 \%$ in CM-5×CM-8, 12.93\% in BARI Mistikumra-1×CM-5, 12.33\% in CM-14×CM-8 and $4.58 \%$ in CM-8 $\times$ CM-1. Most of the crosses showed positive heterosis over standard variety. The highest standard positive heterosis was found $129.01 \%$ in CM$5 \times \mathrm{CM}-20$ followed by $99.25 \%$ in CM-5×CM-8, $92.53 \%$ in BARI Mistikumra- 1 and $46.69 \%$ in CM-8 $\times$ CM-1.

It was observed that the heterosis in the F1 hybrids ranged from $35.50 \%$ to $23.77 \%$ over better parent and positive heterosis over mid parent was maximum $26.65 \%$ in pumpkin ${ }^{(22)}$. Also reported in cucumber (Cucumis satious L.), the relatively low heterosis was found for fruit length in the cross $\mathrm{F} 8 \times \mathrm{M} 3, \mathrm{~F} 7 \times \mathrm{M} 1$ and F6 $\times \mathrm{M} 3{ }^{(24)}$.It was studied heterosis for various traits in $11^{*} 11$ diallel crosses of bitter gourd and observed that the magnitude of heterosis was $11.57 \%$ for fruit length ${ }^{(29)}$. It was reported in bitter gourd that the significant desirable heterosis was observed for fruit length $9.73 \%\left(\mathrm{P} 1{ }^{*} \mathrm{P} 2\right)^{(20)}$. It was found in bitter gourd that the magnitude of heterosis over commercial check (MBTH-101) was very high. It was observed that hetrosis was -34.40 to 7.59 per cent for fruit length of bitter gourd(30). 
Fruit diameter: Fruit diameter ranged from $16.08 \mathrm{~cm}$ to $22.79 \mathrm{~cm}$. Parent CM-1 had the broadest fruits which were followed by parent BARI Mistikumra-1, CM-20 and CM8parents had the narrowest fruits. Among the hybrids, fruit diameter ranged from 14.94 $\mathrm{cm}$ in CM-20×CM-1 to $25.59 \mathrm{~cm}$ in BARI Mistikumra-1×CM-14. Total 15 cross combinations showed positive heterosis over mid parent for this trait. It was ranged $0.65 \%$ in CM-5×BARI Mistikumra-1 to $33.41 \%$ in BARI Mistikumra-1×CM-14. The negative heterosis was varied from $-1.30 \%$ to $-32.11 \%$ over the mid parent. The highest positive heterosis was $33.41 \%$ in BARI Mistikumra- $1 \times \mathrm{CM}-14$ followed by $22.47 \%$ in BARI Mistikumra-1×CM-5, 21.71\% in CM-14×CM-8, 20.79\% in CM-14×CM-1, 19.98\% in CM$8 \times \mathrm{CM}-1,17.10 \%$ in CM-8×CM-14, $12.42 \%$ in CM-1×BARI Mistikumra-1 and $12.19 \%$ in $\mathrm{CM}-8 \times \mathrm{CM}-20$. It was varied from $0.65 \%$ to $33.41 \%$. The highest positive significant heterobeltiotic effect was found $14.84 \%$ in BARI Mistikumra-1×CM-14 followed by

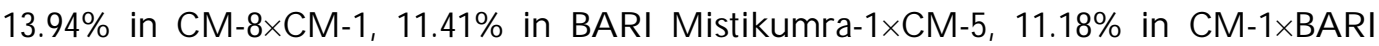
Mistikumra-1 and $10.25 \%$ in CM- $8 \times \mathrm{CM}-20$. The negative heterobeltiotic effect was ranged from $-2.65 \%$ to $-34.44 \%$. Most of the crosses showed negative significant heterosis ranged from $-0.29 \%$ to $-27.83 \%$ over the check commercial variety (Suprema $\mathrm{F}_{1}$ ). The highest positive heterosis showed $25.43 \%$ in $\mathrm{CM}-8 \times \mathrm{CM}-1$ followed by $23.62 \%$ in BARI Mistikumra-1×CM-14, 22.38\% in CM-1×BARI Mistikumra-1, 19.94\% in BARI Mistikumra$1 \times \mathrm{CM}-5$ and $13.06 \%$ in CM-8×CM-20.It was estimated that heterosis in six F1s involving four parental genotypes in ash gourd and found the F1s HF $\times$ Local and MK×Local had desirable better parent heterosis for diameter of green fruits(31). It was studied the heterosis for various traits in $11 \times 11$ diallel crosses of bitter gourd and observed that the magnitude of heterosis in fruit diameter was (106.53\%). Heterobeltiosis showed maximum for fruit diameter $(93.12 \%)^{(29)}$.It was also reported in bitter gourd that the magnitude of heterosis over commercial check (MBTH-101) was high ranged from32.14 to 38.10 for fruit diameter( ${ }^{(30)}$.

Single fruit weight: The mean weight per fruit for six parents varied from $1.20 \mathrm{~kg}$ to $4.58 \mathrm{~kg}$. Parent CM-1 was the heaviest $(4.58 \mathrm{~kg})$ fruit bearing parent which was followed by parent CM-5(3.04kg), CM-14(2.48kg), CM-8(2.20kg), BARI Mistikumra-1(1.93kg) and CM-20 (1.2kg). While in hybrids lines the single fruit weight ranged from $1.96 \mathrm{~kg}$ to $5.68 \mathrm{~kg}$. The per cent of heterosis were ranged from -34.56 to $157.21 \%$ over mid-parental values. The positive heterosis was varied from 0.42 to $157.21 \%$. The highest positive significant heterosis was exhibited by the cross BARI Mistikumra-1XCM-14 (157.21) followed by the crosses CM-8 $\times$ CM-20 (112.55), CM-5×CM-8 (88.93) and BARI Mistikumra-1×CM-20 (82.13). The crosses of CM-1×BARI Mistikumra-1 (50.36), CM8XCM-1 (59.88), CM-1×CM-20 (52.36) also gave good results considering average fruit weight. The positive heterobeltiotic effect was ranged from $6.91 \%$ in CM-1×BARI Mistikumra-1 to $64.24 \%$ in CM-8 $\times \mathrm{CM}-20$. The highest significant positive heterosis over better parent showed 64.24 in $\mathrm{CM}-8 \times \mathrm{CM}-20$. The highest per cent of positive significant 
heterosis was found 198.95\% in BARI Mistikumra-1×CM-14 followed by $185.26 \%$ in CM$8 \times \mathrm{CM}-1,160.53 \%$ in CM-5×CM-8, and $157.72 \%$ in CM-1×BARI Mistikumra-1over check commercial variety (Suprema $\mathrm{F}_{1}$ ) (Table 5). Similar trend of results were reported that fourteen(14), out of 28 crosses showed highly positive heterosis over better parents for average fruit weight, and the estimated maximum heterosis was obtained in CM073 $\times$ CM118 (230.91\%) followed by CM026×CM073 (128.20\%). The crosses of CM073 × CM099 (76.25\%), CM099 X CM120 (60.25\%) and CM118×CM122 (59.13\%) also gave good result considering average fruit weight, while lowest was recorded in CM020 ×CM073 (-29.42) followed by CM020 × CM118 (-28.95), CM044 ×CM073 (-28.11)(27). It was reported the highest significant positive mid and better parent heterosis in the hybrid OP $10 \times$ OP 20 (17.45 \& 16.45) for individual fruit weight of pumpkin ${ }^{(2)}$. It was also found high heterosis over better parent for single fruit weight in pumpkin ${ }^{(26)}$.Also reported all the six F1s of ash gourd exhibited of desirable positive better and mid parent heterosis for fruit weight (31). Similarly, derived information on heterosis for yield components in pumpkin from an 8 X 8 half diallel cross. The hybrid Ambili $\times$ BBS-10 manifested the highest better parent heterosis for average fruit weight $(68.7 \%)^{(28)}$.

Flesh thickness: Only eight cross combinations showed significant positive heterosis over their mid parent values. It was ranged from $3.45 \%$ to $80.74 \%$. The highest significant positive heterosis showed $80.74 \%$ in the cross $\mathrm{CM}-5 \times \mathrm{CM}-8$ followed by BARI Mistikumra-1×CM-14 (39.02\%), CM-1×BARI Mistikumra-1 (15.38\%) and CM-1×CM$20(11.33 \%)$ over mid parent values whereas the lowest value was $-46.60 \%$ in CM-20xCM1. Only six crosses showed positive significant heterosis over better parent values. The highest heterobeltiotic effect was $63.57 \%$ in CM-5XCM-8 followed by BARI Mistikumra$1 \times \mathrm{CM}-14(30.61 \%), \mathrm{CM}-1 \times \mathrm{BARI}$ Mistikumra-1 (8.85\%) and CM-1×CM-20 (6.97\%). On the other hand, only seven crosses showed positive standard heterosis over commercial check (Suprema F1) variety. The highest significant positive heterosis showed $62.22 \%$ in the cross CM-5×CM-8 followed by BARI Mistikumra-1×CM-14 (31.36\%), CM-1×BARI Mistikumra-1 (23.46\%) andCM-1×CM-20 (21.32\%) which were statistical similar, whereas lowest was observed in the cross CM-20×CM-1 (-41.81\%). It was reported that CM $120 \times \mathrm{CM} 122$ showed $28.57 \%$ significant positive heterosis over better parent value ${ }^{(25)}$. Also reported in bitter gourd that the magnitude of heterosis over commercial check (MBTH-101) was very high ${ }^{(30)}$. It ranged -23.74 to 21.10 per cent for flesh thickness which were close conformity.

Number of fruits per plant: The estimation of heterosis indicated the highest (59.18\%) positively significant heterosis over mid parent in hybrid CM-8XCM-1 followed by BARI Mistikumra-1×CM-8 (45.65\%), CM-1×BARI Mistikumra-1 (39.22\%), respectively in case of number of fruits per plant. On other hand the crosses CM-1×CM-8 (38.58\%) and CM$8 \times \mathrm{CM}-20(36.73 \%)$ showed also better performance for this trait. Considering the heterosis over better parent, the highest positively significant heterobeltiotic effect was 
found $44.44 \%$ in CM-8XCM-1 followed by $39.58 \%$ in BARI Mistikumra- $1 \times \mathrm{CM}-8,31.48 \%$ in CM-1×BARI Mistikumra-1. The crosses CM-1×CM-8 and CM-1×CM-20 (25.93\%) and CM-8×CM-20 (24.07\%) could be considered as the most promising for this trait among 30 hybrids. The few of the hybrids showed significantly positive heterosis effect over standard check variety (Suprema $\mathrm{F}_{1}$ ) (Table 5). The highest positive significant heterosis showed by the cross CM- $8 \times \mathrm{CM}-1(28.08 \%)$ followed by CM-1×BARI Mistikumra-1 (16.58\%), CM-1×CM-8 and CM-1×CM-20 (11.66\%) and CM-8×CM-20 (10.02\%). Therefore, these crosses could be considered as the most promising for this trait among 30 hybrids.It was found that high heterosis over better parent for fruits per plant in pumpkin ${ }^{(26)}$. It was recorded that maximum heterosis $(42.12 \%)$ for number of fruits per plant in cucumber hybrid ${ }^{(32)}$.Also reported all the six F1s of ash gourd exhibited of desirable positive better and mid parent heterosis for number of fruits per plant ${ }^{(31)}$. It was reported in cucumber (Cucumis sativus L.), that the highest heterobeltiotic effect was found for number of fruits per plant in hybrid F6×M3 (50\%) followed by F3×M3 (41.67\%), F4×M1 (31.37\%), F8×M1 (31.37\%), F7×M3 (29.17\%) and F3×M1 (25.49\%)(24). To the contrary, also reported that the estimation of heterosis indicated the highest $(105.5 \%)$ positively significant heterosis over better parent in hybrid CM073× CM120 followed by CM020 ×CM073 $(89.0 \%)$ and CM026×CM044 (48.5\%), respectively in case of number of fruits per plant in pumpkin ${ }^{25)}$.

Number of seed per fruit: The maximum number of crosses (25 crosses out of 30 ) exhibited significant positive heterosis over mid parent values for this trait. The highest positively significant heterosis over mid parent was $127.24 \%$ in CM-14×BARI Mistikumra-1 followed by $120.87 \%$ in CM-1×CM-20, $119.73 \%$ in CM-14×CM-5 and $105.29 \%$ in CM-1×CM-14. The crosses of CM-1×BARI Mistikumra-1 (75.05\%), CM-8×CM$1(22.05 \%)$ and BARI Mistikumra-1×CM-20 (59.44\%) also gave good results considering

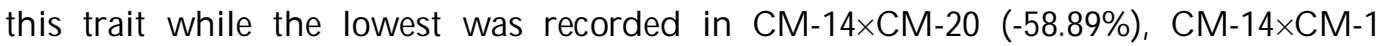
(-29.74\%), CM-5×CM-8 (-24.50\%), CM-5×CM-14(-20.68\%) and CM-8×CM-20 (-13.21\%) over mid parent value of pumpkin. Most of the crosses showed significant positive heterosis over their better parent. The highest heterobeltiotic positively significant effect was found $113.78 \%$ in the cross CM- $1 \times \mathrm{CM}-20$. There is several considerable positive significant heterobeltiotic effect also found in hybrid combinations. Other hand, most of the crosses showed ( 26 crosses out of 30 ) positively significant heterosis over standard check variety (Suprema $\mathrm{F}_{1}$ ). The highest positively significant standard heterotic effect was found $123.80 \%$ in CM-14×CM-5 followed by $187.95 \%$ in CM-1×BARI Mistikumra-1, $150.85 \%$ in CM-1×CM-20 and $111.39 \%$ in the cross CM-8×CM-20. These crosses can be utilized in heterosis breeding program for the improvement of seed yield per fruit in pumpkin. It was reported in bitter gourd that the magnitude of heterosis over commercial check (MBTH-101) was very high. It ranged from -19.73 to 55.27 per cent for number of seeds per fruit of bitter gourd ${ }^{(30)}$. 
100-seed weight $(\mathrm{g})$ : Seed weight is a very important character for pumpkin. Seeds contain larger food material preferably produce vigorous seedlings and have a chance for getting higher yield from that including medicinal value. However, the extent of heterosis over mid parent value ranged from $-0.38 \%$ in cross $\mathrm{CM}-5 \times \mathrm{CM}-1$ to $61.54 \%$ in hybrid CM-1×BARI Mistikumra-1. The significant positive heterosis also followed by $48.08 \%$ in the cross $\mathrm{CM}-8 \times \mathrm{CM}-1$ and $31.98 \%$ in $\mathrm{CM}-1 \times \mathrm{CM}-20$, while the highest heterobeltiotic positively significant effect was found $57.27 \%$ in the cross CM-1×BARI Mistikumra- 1 followed by $36.89 \%$ in the cross CM- $8 \times \mathrm{CM}-1$ and $28.84 \%$ in CM-1×CM-20. Other hand, most of the crosses showed (27 crosses out of 30) negatively significant heterosis over standard check variety (Suprema F1) (Table 5). The highest positively significant standard heterotic effect was found $24.01 \%$ in CM-1×BARI Mistikumra-1 followed by $7.94 \%$ in $\mathrm{CM}-8 \times \mathrm{CM}-1$ and $1.59 \%$ in $\mathrm{CM}-1 \times \mathrm{CM}-20$. Similar findings were recorded ${ }^{(21)}$. It was also observed that the positive significant heterosis ranged from 2.12 to 45.96 per cent over better parent in snake gourd for this trait. It was reported in bitter gourd that the significant negative heterosis was observed for 100 seed weight -29.16 $(\mathrm{P} 5 * \mathrm{P} 6(20)$.

Brix (\%): Among the $30 \mathrm{~F} 1$ combinations 15 showed significant positive heterosis which was ranged from 0.52 per cent to 29.61 per cent brix content. The maximum positive heterosis was observed in cross CM-8×BARI Mistikumra-1 (29.61\%) followed by 26.05 per cent in CM-1×ABRI Mistikumra-1, 25.11 per cent in CM-8×CM-1 and 7.09 per cent in BARI Mistyikumra-1CM-8 over mid parent value in pumpkin. Only four hybrids showed positive heterobeltiotic effect, where the cross CM-1×BARI Mistikumra-1(15.27 $\%$ ) obtained maximum positively significant heterobeltiotic effect followed by CM8xCM-1 (13.23 \%), CM-8×BARI Mistikumra-1(8.32 \%) and CM-14×CM-20 (1.07\%). Other hand, only two hybrids showed positively standard heterotic effect over check variety (Suprema $\mathrm{F}_{1}$ ) (Table 5) where the highest positively significant standard heterotic effect was found $13.39 \%$ in CM-8×CM-1 followed by $8.48 \%$ in CM-8×BARI Mistikumra- 1 , indicating the possibilities of exploiting those crosses for hybrid variety development. The remaining all cross combinations showed negative significant heterosis.It was reported that none of the hybrids showed significant heterosis over mid and better parent for brix content in pumpkin(2).

Yield per plant: Yield per plant is a complex character. It depends on so many characters, such as number of fruit per plant, fruit length, fruit diameter, weight per fruit, days to first flowering and flesh thickness, etc. However, around $50 \%$ of the crosses showed (19 crosses out of 30) positively significant heterosis over mid parent values for yield per plant indicating the possibilities of exploiting those crosses for hybrid variety development. The extent of heterosis over mid parent value ranged from $-62.88 \%$ in cross CM-5×CM-1 to $213.11 \%$ in hybrid CM-8×CM-20. The significant positive heterosis also followed by $136.96 \%$ in the cross CM-8×CM-1, $116.88 \%$ in CM-20×CM-8, $116.71 \%$ in BARI 


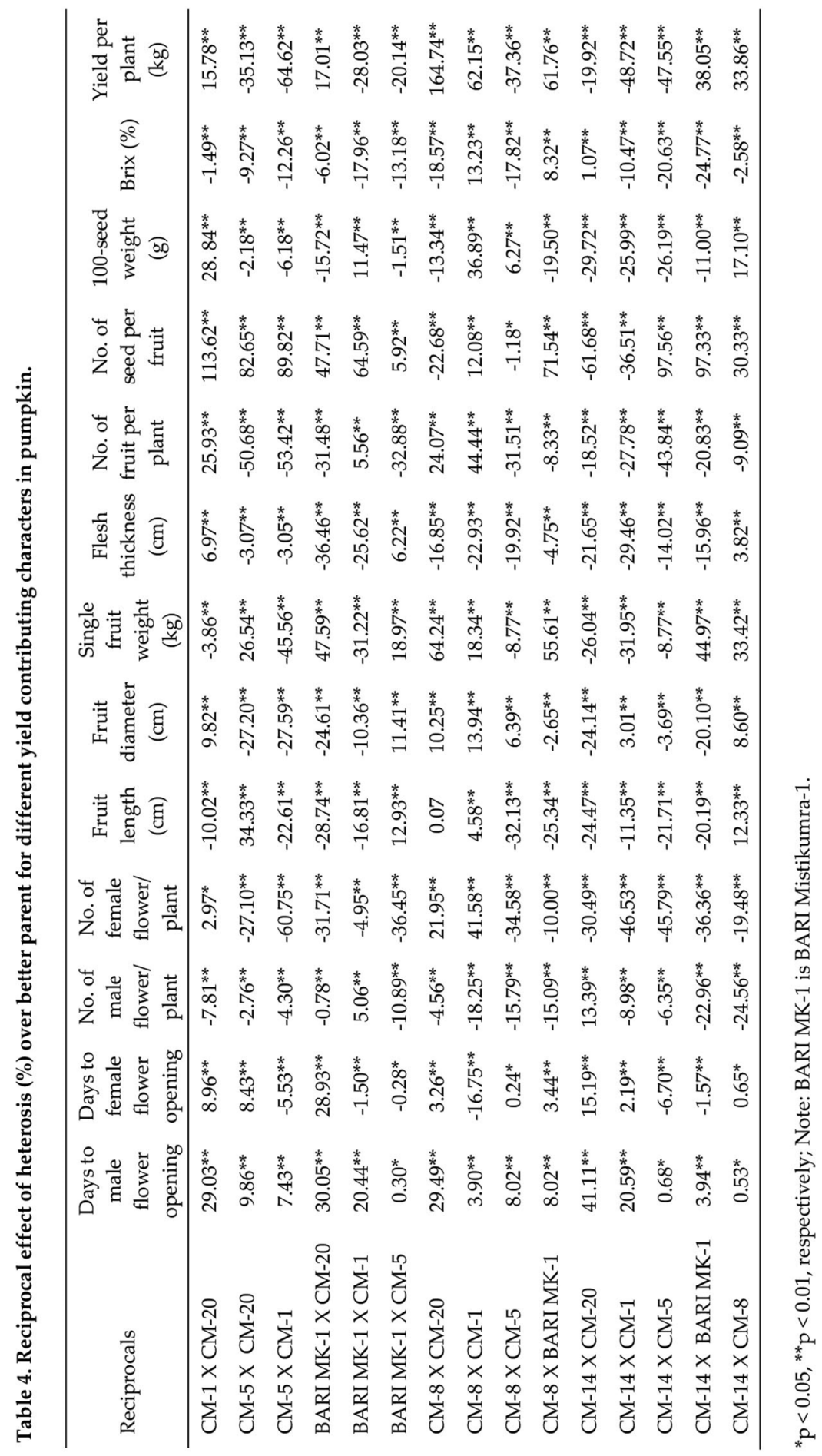




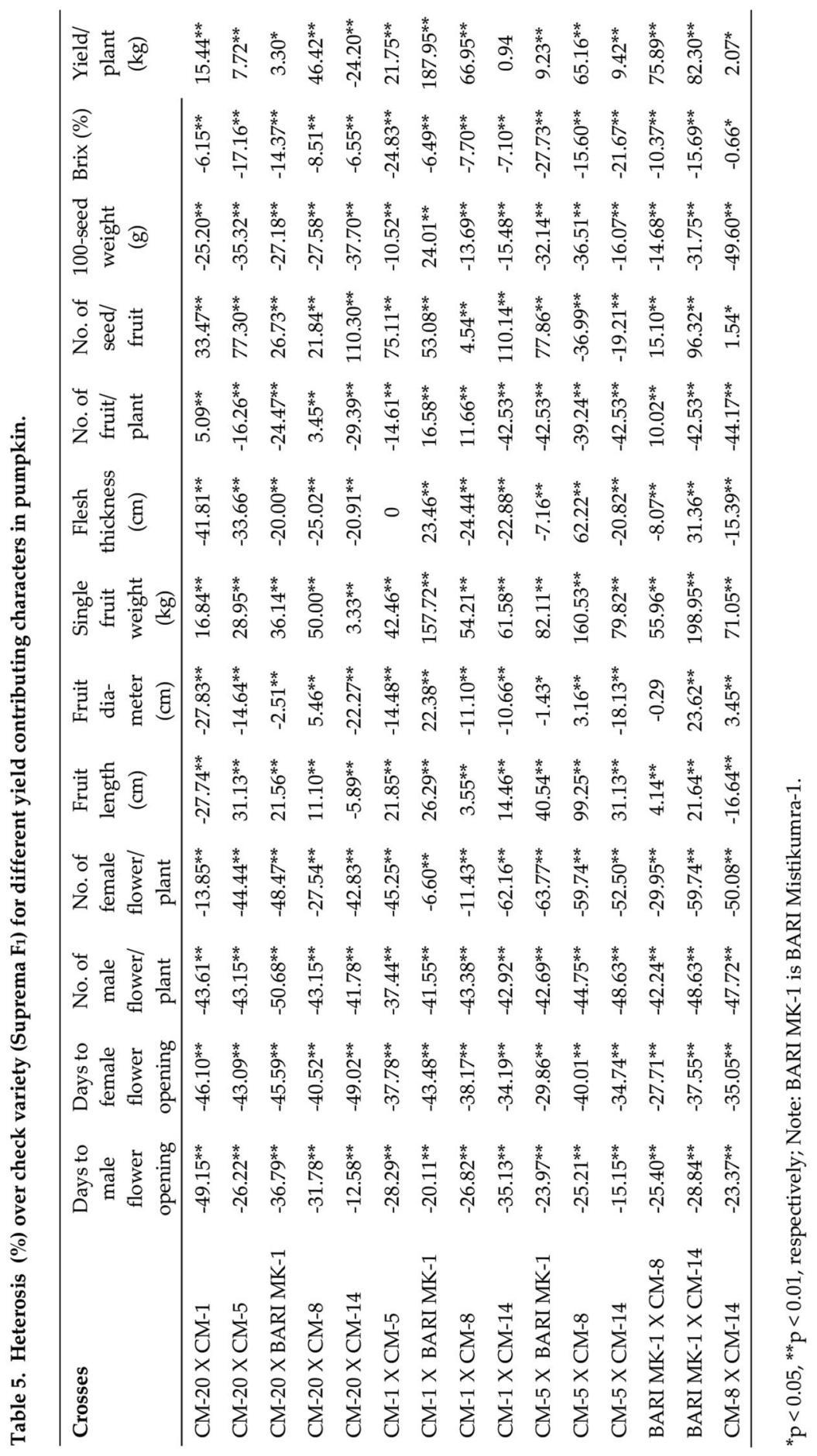




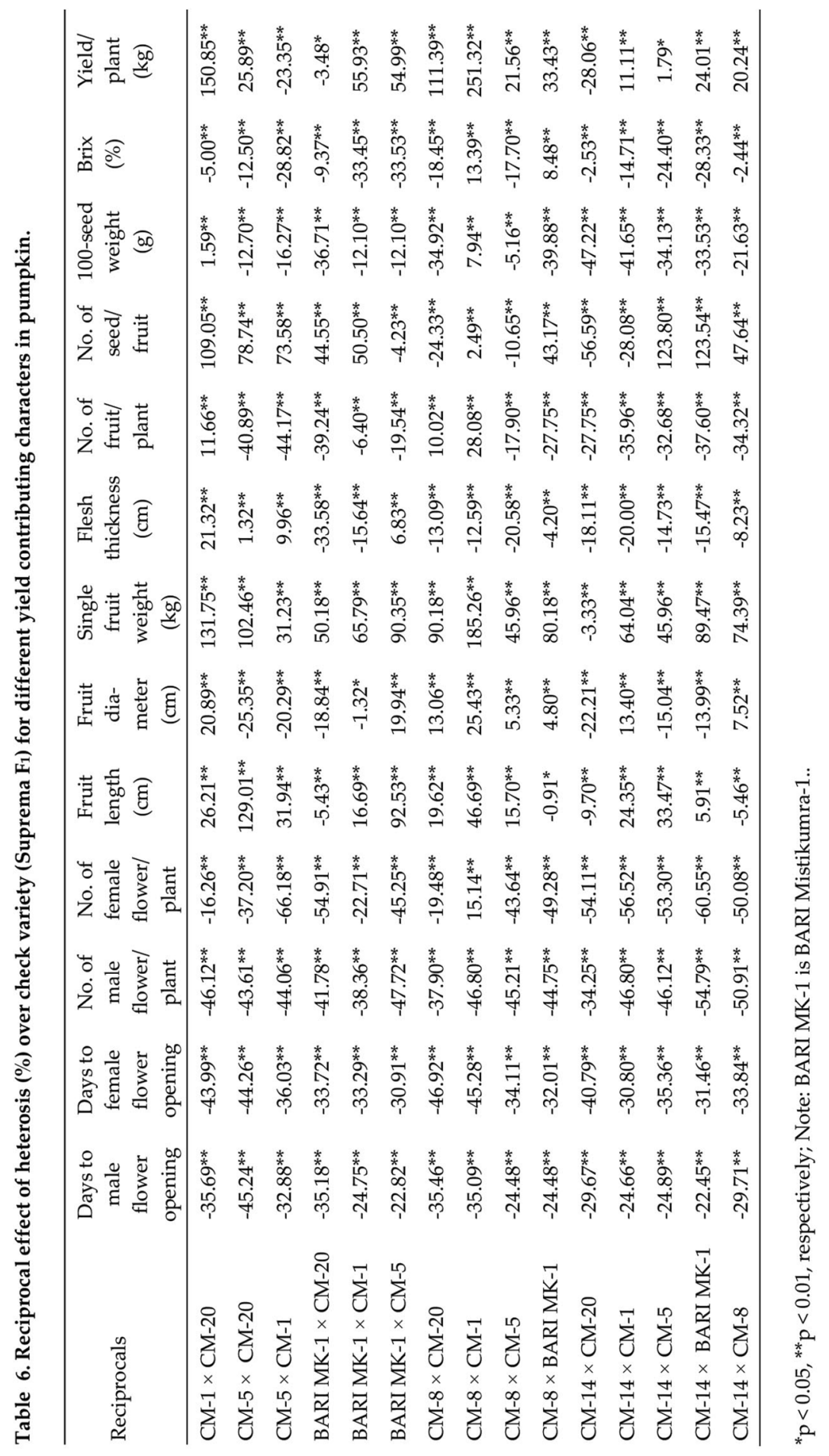


Mistikumra-1×CM-8, $111.58 \%$ in BARI Mistikumra- $1 \times \mathrm{CM}-14$ and $92.51 \%$ in hybrid CM$1 \times$ BARI Mistikumra-1. The highest positive significant heterobeltiotic effect was found $164.74 \%$ in the cross CM-8×CM-20 followed by $113.24 \%$ in BARI Mistikumra- $1 \times \mathrm{CM}-8$, $102.94 \%$ in BARI Mistikumra-1×CM-14, 83.37\% in CM-20×CM-8, 62.15\% in CM-8×CM-1 and $61.76 \%$ in CM-8XBARI Mistikumra-1. The considerable positive significant heterobeltiotic effect also found in CM-14×BARI Mistikumra-1 (38.05\%), CM-14×CM-8 (33.86\%) and CM-1×BARI Mistikumra-1 (31.48\%). Other hand, most of the crosses showed (26 crosses out of 30 ) positively significant heterosis over standard check variety (Suprema F1) (Table 5). The highest positive significant standard heterotic effect was found $251.32 \%$ in CM-8×CM-1 followed by $187.95 \%$ in CM-1×BARI Mistikumra-1, $150.85 \%$ in CM-1×CM-20 and $111.39 \%$ in the cross CM- $8 \times C M-20$. These crosses can be utilized in heterosis breeding program for the improvement of yield per plant in pumpkin. Similar findings was reported(25) that the twenty five crosses out of 28 showed positively significant heterosis over better parent for yield per plant indicating the possibilities of exploiting those crosses for hybrid variety development. The extent of heterosis over better parent ranged from -14.39 to 237.67 . Also reported that high heterosis along with moderately high genetic gain (43.96\%) for yield per plant in pumpkin ${ }^{(28)}$. The mid and better parent heterosis was observed to be as high as $165 \%$ for yield per plant in ash gourd ${ }^{(31)}$.It was reported all the six Fis of ash gourd exhibited of desirable positive better and mid parent heterosis for yield per plant ${ }^{(33)}$. It was also found high heterosis over better parent for yield per plant in pumpkin ${ }^{(26)}$. It explained that the magnitude of heterosis over the commercial check was very high for all the characters studied in bitter gourd ${ }^{(30)}$. It was also reported that both positive and negative heterosis was observed for different qualitative and quantitative characters in $F_{1}$ hybrids in sweet gourd. They recorded the desirable level of mid and better parent heterosis which was exhibited by six and four hybrids, for fruit yield per plant in pumpkin(2).
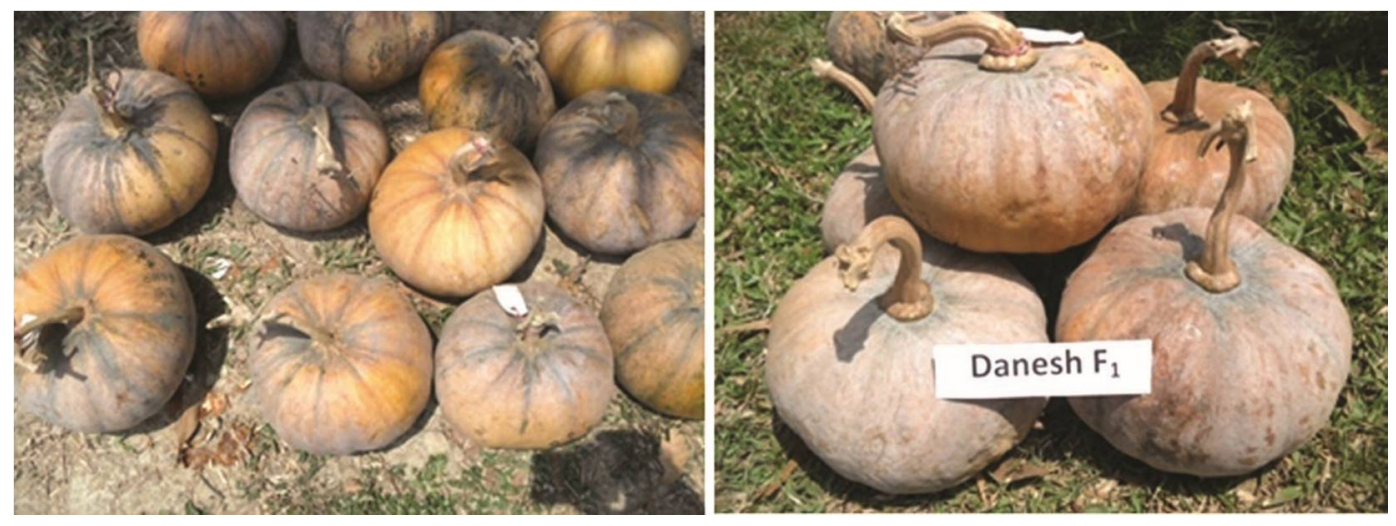

Fig. 1. Showing Hajee (Left) and Danesh (right) hybrid pumpkin variety. 
Reciprocal effect of the crosses: Significant reciprocal effects were observed for the important characters. The cross BARI MISTIKUMRA-1 X CM-1 showed significant negative value for days to female flower opening, number of female flower per plant, single fruit weight, flesh thickness, yield per plant and brix (Table 4). Such results indicated that this cross could be exploited heterotic effects through nuclear inheritance only. The crosses CM-1 X CM-20, had positive reciprocal effects which can be utilized for flesh thickness, single fruit weight, seeds per fruit and yield per plant. These reciprocal effects indicated the to some extent effect of cytoplasmic genes controlling the expression of the characters (Table 6).

Considering yield and yield contributing traits of the studied cross combinations, CM-1 $\times$ BARI Mistikumra-1 and CM- $8 \times$ CM-1 revealed significantly higher heterosis which led to conclude that these two combinations could be the most promising $\mathrm{F}_{1}$ hybrids. In the present study, the cross combination of CM- $1 \times$ BARI Mistikumra- 1 is proposed in the name of Hajee $\mathrm{F}_{1}$ and $\mathrm{CM}-8 \times \mathrm{CM}-1$ as Danesh $\mathrm{F}_{1}$ (Fig. 1). These two combinations were approved and registered as Hajee $F_{1}$ [Reg. no. 01(08)-57] and Danesh $F_{1}[$ Reg. no. 01(08)-56] by National Seed Board (NSB) of Bangladesh.

\section{Conclusions}

Considering the yield and yield contributing traits of cross combinations namely CM-1 × BARI Mistikumra-1 and CM-8 X CM-1 revealed significantly higher heterosis which led to conclude that these two combinations could be the most promising hybrids (F1) of pumpkin. The cross combination of CM- $1 \times$ BARI Mistikumra- 1 is proposed in the name of Hajee F1 and CM- $8 \times \mathrm{CM}-1$ as Danesh F1. These two combinations were approved and registered as Hajee $F_{1}$ [Reg. no. 01(08)-57] and Danesh $F_{1}$ [Reg. no. 01(08)56] by National Seed Board (NSB) of Bangladesh.

\section{References}

1. Katyal SL and ML Chadha 2000. Vegetables Growing in India. Oxford and IBH Publishing Co., New Delhi, India. pp.92-93.

2. Jahan TA, AKMA Islam, MG Rasul, MAK Mian and MM Haque 2012. Heterosis of qualitative and quantitative characters in sweet gourd (Cucurbita moschata Duch.ex Poir). AJFAND online. Published by ASSCAT, Nairobi, Kanya12(3):6186-6199.

3. BBS 2012. Year Book of Agricultural Statistics of Bangladesh, 2010-11. Bangladesh Bureau Statistics. Ministry of Planning. Govt. of the people's Republic of Bangladesh, Dhaka.

4. FAO 2010. Vegetable Statistics. Food and Agriculture Organization of the United Nations, Rome, Italy. http.//www.faostat.fao.org.

5. AVRDC 2011. Inception workshop on improving incomes, nutrition and health in Bangladesh through potato, sweet potato and vegetables, 17-18 January. P. 1

6. Aruah CB, MI Uguru and BC Oyiga 2010. Nutritional evaluation of some Nigerian (Cucurbita Spp) Fruit. Veg. and Cereal Sci and Biotech. 5 (SI2): 64-71. 
7. Atuonwa AC and ENT Akobunda 2010. Nutritional and sensory quality of cockies supplemented with defatted pumpkin (Cucurbita pepo) seed flour. Pk. J. Nutri. 9(7): 672677.

8. Abd El-Aziz $\mathrm{AB}$ and $\mathrm{HH}$ Abd El-Kalek 2011. Antimicrobial protein and oil seeds from pumpkin (Cucurbita moschata). Nature and Sci. 9(3): 105-119.

9. Li QH, Z Tian and TV Cai 2003. Study on the hypoglycemic action of pumpkin extract in diabetic rats. Acta Nutrimenta Sinica 25: 34-36.

10. Wang HK and TB Ng 2003. Isolation of cucumoschin. A novel antifungal peptide abundant in arginine, glutamate and glycine residues from black pumpkin seeds. Peptides 24: 969-972.

11. Fu C, SH Huan and QH Li 2006. A review on pharmacological activities and utilization technologies of pumpkin. Pl. Food Hum. Nutri. J. 61: 70-77.

12. Younis YM, H Seniat GHirmay and SS Al-Shihry 2000. African Cucurbita pepo L. properties of seed and variability in fatty acid composition of seed oil. Phytochem. 54:71-75.

13. Nkosi CZ, AR Opoku and SE Terblanche 2006. Antioxidant effects of pumpkin seeds (Cucurbita pepo L.) protein isolate in CCI-induced liver injury in 4 low-protein fed rats. Phytother. Res. 20: 935-940.

14. Chandra A, BK Verma and RG Satpute 1990. Evaluation of related chilli lines (Capsicum annuиm L.) Veg. Sci. 7: 47-48.

15. Rao DS, RM Singh, H Singh, B khola, OPS and AS Faroda 1990. Correlation and path Coefficient analysis of seed yield and its components in sesame (Sesamum indicum L.). Haryana Agril. Uni. J. Res. 20: 273-276.

16. Rahman SMHE 2006. Genetic Diversity, Combining ability and interrelationships among Yield Components in Sweet Gourd (Cucurbita moschata). Ph.D Dissertation. Dept. of Hort. BAU, Mymensingh, Bangladesh.

17 BARC 2012. Fertilizer Recommendation Guide. Bangladesh Agricultural Research Council (BARC). Farm gate, New Airport Road, Dhaka, Bangladesh. p. 78

18 Somogyi JM 1952. Notes on sugar determination. J. Biol. Chem. 195: 19-23.

19 Fehr WR 1987. Heterosis. In: Principles of Cultivar Development: Theory and Technique (Vol.1). Macmillan Publishing Company, New York. p.115

20. Bimal CK 2008. Morpho-Biochemical Diversity and Heterosis in Bitter gourd (Momordica charantia L.).Ph.D Dissertation. Dept. of Hort. BSMRAU, Salna, Gazipur. Bangladesh.

21. Banik, B. R. 2003. Variability, gene action and heterosis in snake gourd (Trichosanthes anguina L.). Ph.D. Dissertation. Dept. Genet. Pl. Breed., BSMRAU, Salna, Gazipur, Bangladesh.

22. Hossain MS 1996. Heterosis and combining ability for yield, yield components and plant characters in sweet gourd (Cucurbita moschata Duch ex Poir.). MS thesis. Dept. of Genet. Pl. Breed., Bangladesh Agricultural University, Mymensingh, Bangladesh.

23. Islam MN 1993. Studies on heterosis and combining ability in bottle gourd. M.Sc. Thesis, Dept. of Genet. and Pl. Breed., Bangladesh Agril. Univ. Mymensingh, Bangladesh. pp.1-98.

24. Uddin MN 2008. Morpho-Molecular characterization, Diversity and Heterosis in cucumber (Cucumis sativus L.).Ph.D Dissertation. Dept. of Hort. BSMRAU, Salna, Gazipur. 1-190.

25. Rahman MM, SK Dey and M Wazuddin 1991. Study of Yield and yield components and vine characters of some cucurbit genotypes. BAU Res. Progress, 5: 75-85.

26. Mohanty BK and RS Mishra 2004. Studies on heterosis for yield and yield attributes in pumpkin (Cucurbita moschata Duch. ex. Poir). Ind. J. Hort. 56(2): 173-178. 
27. Rahman MM, SK Dey and M Wazuddin 1990. Yield and yield components and plant characters of several bitter gourds, ribbed gourd, bottle gourd and sweet gourd genotypes. BAU Res. Progress, 4: 117-127.

28. Mohanty BK and RS Mishra 1999. Studies on heterosis for flowering attributes in pumpkin (Cucurbita moschata Duch. ex. Poir). South Ind. Hort. J. 47(1-6): 203-205.

29. Chaudhary SM 1987. Studies on heterosis, combining ability and correlation in bitter gourd (Momordica charantia L.). Ph.D. Thesis. Mahatma Phule Agril. Univ, Rahuri, Maharashtra, India.

30. Laxuman 2005. Studies on diversity, heterosis and combining ability in bitter gourd (Momordica charantia L.). M.Sc. (Ag) Thesis, Dept. of Genet. and Plant Breed., College of Agriculture, Dharwad Univ. Agril. Sci., Dharwad-580 005, India.

31. Karim MS, M Ali and MAK Mian 2001. Heterosis in ash gourd [Benincasa hispida (Thumb) Cogn.]. Bangladesh J. Pl. Breed. Genet. 14(1): 21-28.

32. Solanki SS, JN Seth and SD Lal 1982. Heterosis and inbreeding depression in cucumber. Prog. Hort. 14: 121-125.

33. Verma VK and TK Behera 2007. Heterosis studies in ash gourd [Benincasa hispida (Thumb) Cogn.] for yield and related traits. J. Trop. Agric. 45(1\&2): 51-54. 